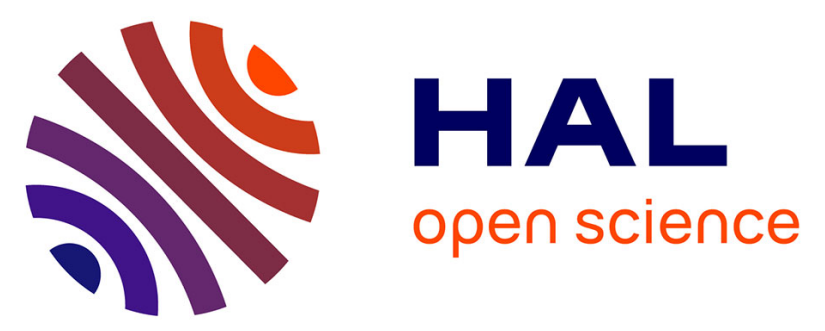

\title{
Isoprene and monoterpenes biogenic emissions in France: modeling and impact during a regional pollution episode
}

\author{
F. Solmon, C. Sarrat, Dominique Serça, Pierre Tulet, R. Rosset
}

\section{To cite this version:}

F. Solmon, C. Sarrat, Dominique Serça, Pierre Tulet, R. Rosset. Isoprene and monoterpenes biogenic emissions in France: modeling and impact during a regional pollution episode. Atmospheric environment, 2004, 38, pp.3853-3865. 10.1016/j.atmosenv.2004.03.054 . hal-00136319

\section{HAL Id: hal-00136319 \\ https://hal.science/hal-00136319}

Submitted on 27 May 2021

HAL is a multi-disciplinary open access archive for the deposit and dissemination of scientific research documents, whether they are published or not. The documents may come from teaching and research institutions in France or abroad, or from public or private research centers.
L'archive ouverte pluridisciplinaire HAL, est destinée au dépôt et à la diffusion de documents scientifiques de niveau recherche, publiés ou non, émanant des établissements d'enseignement et de recherche français ou étrangers, des laboratoires publics ou privés. 


\title{
Isoprene and monoterpenes biogenic emissions in France: modeling and impact during a regional pollution episode
}

\author{
Fabien Solmon*, Claire Sarrat, Dominique Serça, Pierre Tulet, Robert Rosset \\ Laboratoire d'Aérologie, 14 Avenue Edouard Belin, 31400 Toulouse, France
}

\begin{abstract}
Biogenic emission of isoprene and monoterpenes are modeled in order to study their impact on regional atmospheric chemistry and pollutionin France. First, an emission potential inventory is devel oped using a fine scal e landuse database, forest composition statistics, biometric data and species emission factors. Considering the main emission patterns, the results show consistency with previously published European and global inventories. When downscaling to sub-region of France, this database is likely to provide refined sources distribution, an important issue for regional atmospheric chemistry studies. The temporal evolution of biogenic fluxes with meteorological conditions is calculated on 1 inein the MesoNH-C meso-scal eatmospheric chemistry model .Leaf-l evelal gorithmsare integrated at the ecosystem scal e using sub-grid prognostic surface temperature and canopy shading effects. Final $1 \mathrm{y}$,ecosystem to landscape integration is performed by aggregating biogenic fluxes at the model grid cell scale. Uncertainties associated with these estimations are discussed with respect to different spatial scal es.In the second part of the paper, these devel opmentsare used to study biogenic emission impacts on regional ozone formation. We focus on a summer poll utionevent over Paris and northern France, documented during the ESQUIF experiment. The introduction of biogenic fluxes led to an increase in simulated surface ozone concentrations, reaching $18-30 \%$ in the Paris plume and about $20-30 \%$ in some rural areas. This impact was mainl y due to large biogenic fluxes as wellas to the chemical conditions prevailing in the anthropogenic plumes reaching biogenic sources. In this situation, some comparisons with air quality measurements pointed out an improvement of simulated ozone concentrations when accounting for biogenic fluxes, both in urban plumes and over rural areas.
\end{abstract}

Keywords: Isoprene; Monoterpenes; Emission inventories; Regional pollution; Atmospheric chemistry modeling

\section{Introduction}

Biogenic volatile organic compounds (BVOC) such as isoprene and monoterpenes are recognized to play key roles in atmospheric chemistry processes, ranging from local scale to global scale (Guenther et al., 1995). In particular, the tropospheric production of ozone due to

*Corresponding author. Abdus Salam International Center for Theoretical Physics, PWC group, Trieste, Italy. Fax: +39 040224163.

E-mail address: solmon@ictp.trieste.it (F. Solmon). photochemical reactions of nitrogen oxides $\left(\mathrm{NO}_{x}\right)$ is enhanced by the presence of BVOC, which are very reactive compared to most of the anthropogenic VOC (Stockwell et al., 1997). The impact of biogenic emission on ozone pollution is likely to be significant in urban area (Chameides et al., 1988) and very important in rural sites (Tsigaridis and Kanankidou, 2002). Therefore, control policies on primary pollutant emission need to account for biogenic emissions as accurately as possible (Pierce et al., 1998). At the regional scale, the spatial extent and spreading of biogenic sources in the landscape favors complex interactions with pollutant plumes 
which determine the regional ozone budget (Sillman, 1999). Indeed, the inclusion of biogenic emissions in regional atmospheric chemistry model has been a topic of interest for the last 15 years (Guenther, 1999). One important aspect of such studies lies on the representation of biologically regulated emission in simple models (Guenther et al., 2000; Fall and Wildermuth, 1998) designed to simulate emissions for a wide range of vegetation species and landscapes.

In such a context, the present paper aims at presenting a simple biogenic emission scheme used in the French meso-scale chemical model MesoNH-C (Tulet et al., 1999, 2003; Crassier et al., 2000). Section 2 describes the methodology and the data used for that purpose. In Section 3, these developments are used to investigate the chemical impact of biogenic emissions during an episode of regional pollution over Paris and northern France. Finally, the Section 4 will draws out conclusions and perspectives to this work.

\section{Regional modeling of biogenic emissions over France}

For a model grid-cell, biogenic fluxes are calculated according to the classical Guenther's approach (Guenther et al.,1994, 1995; Pierce et al., 1998), using the general formulation:

$F_{x}^{\mathrm{cell}}=\sum_{N} \eta_{n} \times \mathrm{EP}_{x, n} \times \mathrm{ECF}_{x, n}$,

where $F_{x}^{\text {cell }}$ (in $\mu \mathrm{g} \mathrm{m}^{-2} \mathrm{~h}^{-1}$ ) is the grid-cell averaged biogenic fluxes in which $x$ refers either to isoprene or monoterpenes. $\eta_{n}$ represents the surface fractions occupied by $N$ sub-grid emitting ecosystems (forests, shrublands, crops, etc). The related emission potential, $\mathrm{EP}_{x, n}$, (in $\mu \mathrm{g} \mathrm{m}^{-2} \mathrm{~h}^{-1}$ ), accounts for the emission capacity of the underlying $n$th ecosystem under fixed climatic conditions. According to Guenther's approach, $\mathrm{EP}_{\text {iso }}$ is standardized to a surface vegetation temperature
$T_{\mathrm{s}}$ of $30^{\circ} \mathrm{C}$ and a photosynthetically active radiation (par) of $1000 \mu \mathrm{E} \mathrm{m}^{-2} \mathrm{~s}^{-1}$, whereas $\mathrm{EP}_{\text {mono }}$ is generally standardized only for $T_{\mathrm{s}}=30^{\circ} \mathrm{C}$. The temporal evolution of fluxes is given by environmental correction factors $\mathrm{ECF}_{x, n}$ calculated from the canopy micro-climates of the $N$ underlying ecosystems. This formulation assumes a simple homogeneous vertical leaf distribution in ecosystem canopies. Forthcoming sections focus on the determination of $\mathrm{EP}_{x, n}$ and $\mathrm{ECF}_{x, n}$ over French regions.

\subsection{Emission potentials}

\subsubsection{Characterization of emitting ecosystems in France}

Ecosystems are defined from the Corine Land Cover (CLC) landuse database, provided by "Institut Français de l'Environnement" (IFEN; http://www.ifen.fr/). We considered the ligneous vegetation as main emitter, including "broad-leaved forest (BL)", "coniferous forest (C)", "mixed forest (M)", "shrubland (S)" and "other ligneous (OL)" (see Table 1 for a description). "crops (CR)", as well as "grassland and pasture (GR)" which are weaker emitters were also considered. The CLC database is derived from satellite data (SPOT, LANDSAT-TM, 1987-1994) and ground observations (see CLC report published by Commission of the European Communities OPOCE, ECSC-EEC-EAEC, Brussels, Luxembourg, 1991). The smallest resolved spatial unit is about 25 ha with a mapping precision of $50-100 \mathrm{~m}$. Biases inherent to satellite measurements and photointerpretation of land surfaces could affect the precision of this landuse classification. However, such errors are difficult to quantify over extended areas and therefore not taken into account.

For each ecosystem, a species composition was determined. For forests we used data provided by the French National Inventory (IFN), an institute in charge of forestry resources estimations. In order to statistically characterize tree populations, IFN has developed a

Table 1

Characteristics and identification criteria of CORINE LAND COVER ligneous vegetation classes considered as primary isoprene and monoterpenes potential emitters in this study. Secondary emitters like crops and grassland are also accounted for (see text)

\begin{tabular}{|c|c|c|c|c|c|}
\hline & $\begin{array}{l}\text { Broad-leaved } \\
(\mathrm{BL})\end{array}$ & $\begin{array}{l}\text { Coniferous } \\
\text { (C) }\end{array}$ & $\begin{array}{l}\text { Mixed } \\
\text { (M) }\end{array}$ & $\begin{array}{l}\text { Sclerophyllous } \\
\text { (S) }\end{array}$ & $\begin{array}{l}\text { Other ligneous } \\
(\mathrm{OL})\end{array}$ \\
\hline $\begin{array}{l}\text { Type of } \\
\text { vegetation }\end{array}$ & $\begin{array}{l}\text { Forests of tall } \\
\text { trees, coppices, } \\
\text { plantations } \\
\text { (Poplar) }\end{array}$ & $\begin{array}{l}\text { Forests of tall } \\
\text { trees, coppices, } \\
\text { plantations }\end{array}$ & $\begin{array}{l}\text { Tree mixing, Grove } \\
\text { mixing Mosaic of } \mathrm{BL} \text {, } \\
\mathrm{C} \text { (patches }<25 \text { ha) }\end{array}$ & $\begin{array}{l}\text { Low ligneous } \\
\text { Low to dense } \\
\text { Med. vegetation } \\
\text { "Maquis", } \\
\text { "Garrigue", }\end{array}$ & $\begin{array}{l}\text { Moorland } \\
\text { Heathland } \\
\text { Schrubland }\end{array}$ \\
\hline $\begin{array}{l}\text { Identification } \\
\text { criteria }\end{array}$ & $\begin{array}{l}\text { Spatial } \\
\text { occupation rate } \\
\text { of } \mathrm{BL}>75 \%\end{array}$ & $\begin{array}{l}\text { Spatial } \\
\text { occupation rate } \\
\text { of } \mathrm{C}>75 \%\end{array}$ & $\begin{array}{l}\text { Spatial occupation rate } \\
25 \%<\mathrm{BL}<75 \% \\
25 \%<\mathrm{C}<75 \%\end{array}$ & $\begin{array}{l}\text { Use of ancillary } \\
\text { information } \\
\text { (species, soil } \\
\text { types) }\end{array}$ & $\begin{array}{l}\text { Use of ancillary } \\
\text { information } \\
\text { (species, soil } \\
\text { types) }\end{array}$ \\
\hline
\end{tabular}


nesting sampling scheme based on field-collected biometric data, satellite imagery and aerial photography. A detailed description of this scheme can be found in Chevrou (1988) or on the IFN website (http:/ www.ifn.fr). Based on these studies, the IFN has divided the country into 309 distinct "forestry regions" according to a homogeneity criteria that takes into account climate, topography, soil geology and the dominant tree species. In a given forestry region, the ecological variability of the three $\mathrm{BL}, \mathrm{C}$, and $\mathrm{M}$ ecosystems should be lower than for any other partition of the territory (e.g. administrative region). Thus, the $\mathrm{BL}, \mathrm{C}$ and $\mathrm{M}$ forests have been characterized by their mean species composition. At the scale of France, it means that we considered $927(309 \times 3)$ distinct forest ecosystems geographically distributed according to CLC landuse and forestry region boundaries. The canopy mean compositions were defined on the basis of the 24 main French tree species (see Table 2). The species cover rates $\tau_{i},(i=1,24)$ were provided by IFN, as well as their stem diameter $(\mathrm{DBH})$ distributions which is used for leaf biomass estimations.

\subsubsection{Emission potential calculations}

2.1.2.1. Forest ecosystems. For a given forest ecosystem, the canopy emission potential $\mathrm{EP}_{x}$ has been determined through the up-scaling of standardized leaf-level species emission factors $\mathrm{EF}_{x}$, according to the following equation.

$\mathrm{EP}_{x}=\sum_{i}^{N_{\text {sp }}} \tau_{i} \mathrm{EF}_{x, i} \mathrm{Bm}_{i}$,

where $\tau_{i}$ is the species cover rate, $N_{\mathrm{sp}}=24$ is the number of species in the ecosystem, and $\mathrm{Bm}_{i}$ is the specific foliar biomass density $\left(\mathrm{g}_{\mathrm{dw}} \mathrm{m}^{-2}\right)$.

2.1.2.2. Emission factor database. Table 2a summarizes the emission factors of the main tree species considered in this study. Most of the emission factor data have either been provided by Kesselmeier and Staudt, (1999), or found in the reference database of the Lancaster University (http://www.es.lancs.ac.uk/cnhgroup/cover. html). Emission factors are known to exhibit large inter-species and intra-species variability, mainly due to physiological and environmental causes like seasonality, stresses, age of plants, prior weather growth conditions, etc. (Monson et al.,1994; Fall and Wildermuth, 1998; Staudt et al., 1999). Consequently, different emission factors can be found in the literature for several tree species (e.g. for Quercus robur, Quercus petraea, Quercus pubescens, Quercus ilex, Pinus sylvestris or Pinus pinaster). For such cases, the averaged values were considered and emission factors measured during summer were selected first. For cases in which data were missing, emission factors were determined using the taxonomic method based on genus averaging. Ensuing uncertainties can be considerable (Benjamin et al., 1996), however the method was not used for dominant oaks. "Other broad-leaved" and "other coniferous" classes grouped together "minor" species at the national scale (accounting for less than $5 \%$ of the total forested area), but which can be significant emitters locally. Main species constituting these minor classes are Tilia sp., Prunus sp., Acer sp., Eucalyptus globulus, and Quercus cerris for "other broad-leaved", and Picea stichensis, Pinus pinea and Pinus mugo for "other coniferous". In Table 2a, default mean emission factors were assigned to these categories.

2.1.2.3. Species leaf biomass estimations. For a given canopy, the species leaf biomass $\mathrm{Bm}_{i}$ was determined using the following relationship:

$\mathrm{Bm}_{i}=\mathrm{Ms}_{i} \times \sum_{\mathrm{DBH}}\left(\rho_{i, d} \times \mathrm{LA}_{i, d}\right)$,

where $\rho_{i, d}$ is the distribution of stems population in DBH sections (index $d$ ) for species $i$ (provided by IFN), $\mathrm{Ms}_{i}$ $\left(\mathrm{g}_{\mathrm{dw}} \mathrm{m}_{\text {leaf }}^{-2}\right)$ is the specific leaf weight relative to species $i$ in the canopy, and $\mathbf{L A}_{i, d}$ is an estimated tree leaf area for a given DBH and for the $i$ th species. Estimates of $\mathrm{Ms}_{i}$ have been obtained from the literature (Table 2a). This parameter is subject to a large variability within a given canopy (e.g. "sun leaves" vs. "shade leaves"). Ecological and physical environments (cover density, nutriment availability) are also known to affect $\mathrm{Ms}_{i}$ (Gower et al., 1999): in this simple approach, species averaged values of $\mathrm{Ms}_{i}$ were considered. The tree leaf areas (LA) were empirically estimated using specific allometric relationships (Table 2a). Generally, relationships of the form $\log (\mathrm{LA})=a+b \log (\mathrm{DBH})$ were considered. Again, several environmental factors may influence such estimations (Gower et al., 1999), resulting in uncertainties when extrapolated to large scales. When no specific relations were found, we used identical allometric relationships for species belonging to a same genus and displaying morphological similarities (e.g.: Q. robur and Q. petraea). When this was not possible, we attributed representative tree LA derived from literature. Finally, we assumed a default LA index of 3.5 for some broad-leaved species, and 4.5 for 'other coniferous'.

2.1.2.4. Other biogenic emitters (Table 2b). The sclerophyllous vegetation (S) was directly characterized by a bulk emission potential that accounts for typical species and biomass. The values selected for S category were taken from tower measurements made during the BEMA 95 experiment over a Garrigue ecosystem (Owen et al., 1998). The OL emission potential value has been taken from Simpson et al. (1999) for moorland/ heathland. Similarly, values for CR and GR categories were taken from Simpson et al. (1999). 
Table 2

Dominant tree species in France, their total coverage estimated by IFN and a bibliographic database for species emission factors, specific leaf weights and allometric relationships

\begin{tabular}{|c|c|c|c|c|c|}
\hline (a) Species & $\begin{array}{l}\text { Total surface } \\
\left(\times 10^{5} \text { ha }\right)\end{array}$ & $\begin{array}{l}\text { EFiso (Ref.) } \\
\left(\mu \mathrm{gg}_{\mathrm{DW}}^{-1} \mathrm{~h}^{-1}\right)\end{array}$ & $\begin{array}{l}\text { EFmono (Ref.) } \\
\left(\mu \mathrm{g} \mathrm{g}_{\mathrm{DW}}^{-1} \mathrm{~h}^{-1}\right.\end{array}$ & $\begin{array}{l}\text { Ms (Ref.) } \\
\left(\mathrm{g}_{\mathrm{DW}} \mathrm{m}_{\text {leaf }}^{-2}\right)\end{array}$ & Ref. R.A \\
\hline Quercus robur & 23.04 & $76(1)$ & $0(1)$ & $107(13)$ & (19) \\
\hline Quercus petraea & 18.59 & $66(2)$ & $0(2)$ & $129(13)$ & (19) \\
\hline Quercus pubescens & 8.90 & $68(3)$ & $0(3)$ & $120(14)$ & (20) \\
\hline Quercus ilex & 2.88 & $0(1)$ & $17(1)$ & $150(14)$ & $(20)$ \\
\hline Quercus suber & 0.65 & $0(4)$ & $8(4)$ & $150(14)$ & (20) \\
\hline Fagus sylvatica & 12.83 & $0(1)$ & $0.3(1)$ & $60(15)$ & (21) \\
\hline Castanea sativa & 4.71 & $0(5)$ & $13(5)$ & $80(\mathrm{~T})$ & (20) \\
\hline Carpinus betulus & 2.09 & $0(1)$ & $0(1)$ & $80(\mathrm{~T})$ & (22) \\
\hline Betula sp. & 1.57 & $0(6)$ & $2.9(2)$ & $82(16)$ & (D) \\
\hline Alnus sp. & 0.79 & $0(7)$ & $0(7)$ & $80(\mathrm{~T})$ & (D) \\
\hline Robinia pseuso-acacia & 1.31 & $151(8)$ & $5(1)$ & $64(8)$ & (D) \\
\hline Fraxinus sp. & 3.40 & $0(1)$ & $0(1)$ & $65(17)$ & (D) \\
\hline Populus tremula & 0.52 & $45(8)$ & $5(1)$ & $87(16)$ & (16) \\
\hline Salix sp. & 0.47 & $32(1)$ & $0.3(1)$ & $84(16)$ & (D) \\
\hline Other broad-leaved & 2.88 & $10(\mathrm{D})$ & $0.5(\mathrm{D})$ & $80(\mathrm{~T})$ & (D) \\
\hline Pinus pinaster & 13.09 & $0(1)$ & $1.7(2)$ & $91(17)$ & (D) \\
\hline Pinus sylvestris & 11.26 & $0(1)$ & $6(1)$ & $91(\mathrm{~T})$ & (25) \\
\hline Pinus nigra ssp. laricio & 1.31 & $0(\mathrm{~T})$ & $1(\mathrm{~T})$ & $91(\mathrm{~T})$ & (23) \\
\hline Pinus nigra & 1.83 & $0(\mathrm{~T})$ & $1(\mathrm{~T})$ & $91(\mathrm{~T})$ & (23) \\
\hline Pinus halepensis & 2.36 & $0 .(9)$ & $2(9)$ & $91(\mathrm{~T})$ & (24) \\
\hline Pinus uncinata & 0.52 & $0(\mathrm{~T})$ & $1(\mathrm{~T})$ & $91(\mathrm{~T})$ & (23) \\
\hline Abies alba & 5.50 & $0.5(26)$ & $3(11)$ & $150(\mathrm{~T})$ & (23) \\
\hline Picea abies & 7.33 & $1(1)$ & $4.5(1)$ & $150(\mathrm{~T})$ & (23) \\
\hline Larix decidua & 1.05 & $0(10)$ & $8(10)$ & $91(\mathrm{~T})$ & (24) \\
\hline Pseudotsuga menziesii & 3.40 & $0(1)$ & $2.5(1)$ & $172(17)$ & (24) \\
\hline Other coniferous & 1.57 & 1 (D) & 3 (D) & 90 (D) & (D) \\
\hline (b) Ecosystem & \multicolumn{2}{|c|}{ EFiso $^{c}$ (Ref.) $\mu g_{\text {DW }}^{-1} h^{-1}$} & \multicolumn{2}{|c|}{ EFmono $^{c}$ (Ref.) $\mu g_{\text {DW }}^{-1} h^{-1}$} & $\begin{array}{l}\text { Bm (Ref.) } \\
\mathrm{g}_{\mathrm{DW}} \mathrm{m}^{-2}\end{array}$ \\
\hline S & \multicolumn{2}{|c|}{$7.2(12)$} & \multicolumn{2}{|c|}{$1(12)$} & $375(6)$ \\
\hline OL & \multicolumn{2}{|c|}{$8(26)$} & \multicolumn{2}{|c|}{$0.6(26)$} & $200(26)$ \\
\hline GR & \multicolumn{2}{|c|}{$0.1(26)$} & \multicolumn{2}{|c|}{$0.1(26)$} & $400(26)$ \\
\hline CR & \multicolumn{2}{|c|}{$0(26)$} & \multicolumn{2}{|c|}{$0.1(26)$} & $1000(26)$ \\
\hline
\end{tabular}

EFiso: leaf-level isoprene emission factors; EFmono: leaf-level monoterpenes emission factors; Ms: specific leaf weights; R.A: allometric relationships used to derive the tree-level representative leaf area. EFiso ${ }^{c}$ : ecosystem-level isoprene emission factors. EFmono $^{c}$ : ecosystem-level monoterpenes emission factors. Bm: ecosystem representative biomass. References: (1) Kesselmeier and Staudt (1999). (2) Steinbrecher et al. (1997). (3) Seufert et al. (1997); Steinbrecher and Hauff (1996); Kesselmeier et al. (1998); Steinbrecher et al. (1997). (4) Rasmussen (1978); Seufert et al. (1997); Steinbrecher et al. (1997); Pio et al. (1993). (5) Rasmussen (1978); Pio et al. (1993). (6) Flyckt et al. (1980); Steinbrecher et al. (1997). (7) Steinbrecher (1997); Steinbrecher et al. (1993). (8) Geron et al., 2001. (9) Corchnoy et al. (1992); Owen et al. (1998). (10) Isidorov et al. (1985). (11) Benjamin et al. (1996). (12) Owen et al. (1998). (13) Breda, personnal communication. (14) Rambal, personnal communication. (15) Bartelink (1997). (16) Niinemets and Kalevi (1994). (17) Cabanettes and Rapp, personnal communication. (18) Granier (1981). (19) Dufresne and Breda (1995). (20) Damesin et al. (1998). (21) Martin et al. (1998). (22) Geron and Ruark (1988). (23) Cabanettes and Rapp (1978). (24) Gower and Norman (1991). (25) Duchemin (1999). (26) Simpson et al. (1999). (T): Taxinomic method applied (see text); (D): Default representative values are used (see text).

\subsubsection{Emission potentials at the landscape level, uncertainties}

Figs. 1a and c are GIS aggregated maps of resulting emission potentials at $2 \mathrm{~km}$ resolution. The validity of such data is difficult to evaluate considering the cascade of uncertainties encountered, from emission factor to landscape heterogeneity. Therefore, different spatial scales should be considered for an analysis.

(i) Focusing on the main isoprene emission patterns over the country, the highest emission potentials are found for forest pixels dominated by $Q$. robur and $Q$. petraea 


\section{Isoprene emission potential}

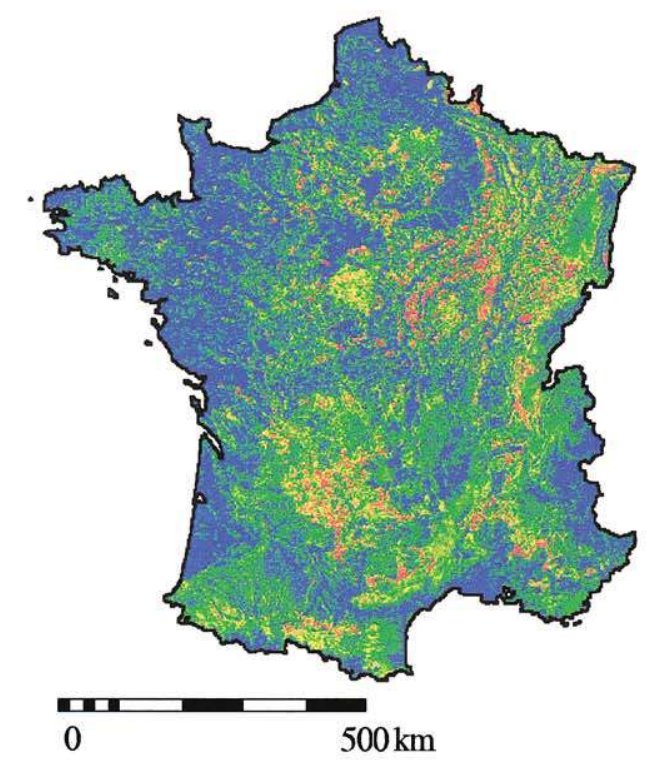

(a)

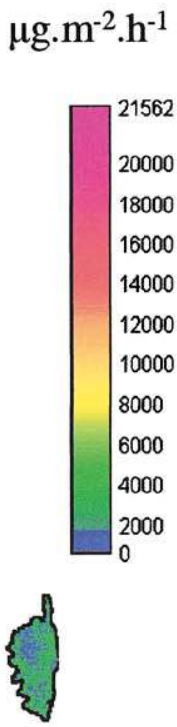

(b)

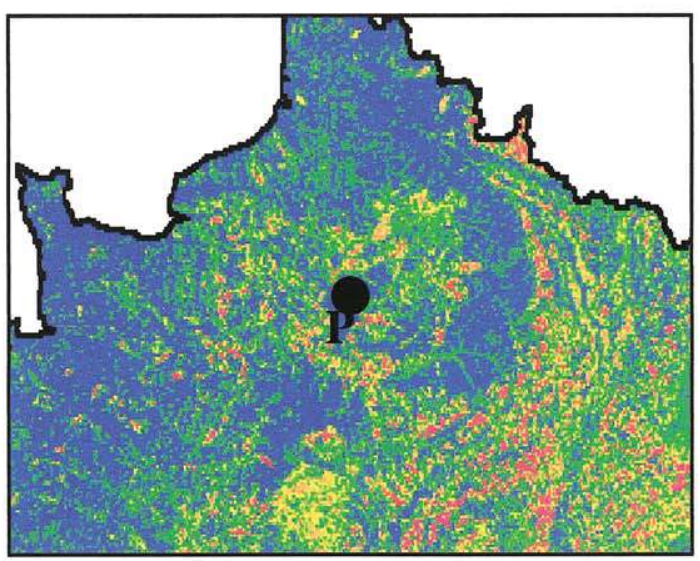

\section{Monoterpenes emission potential}

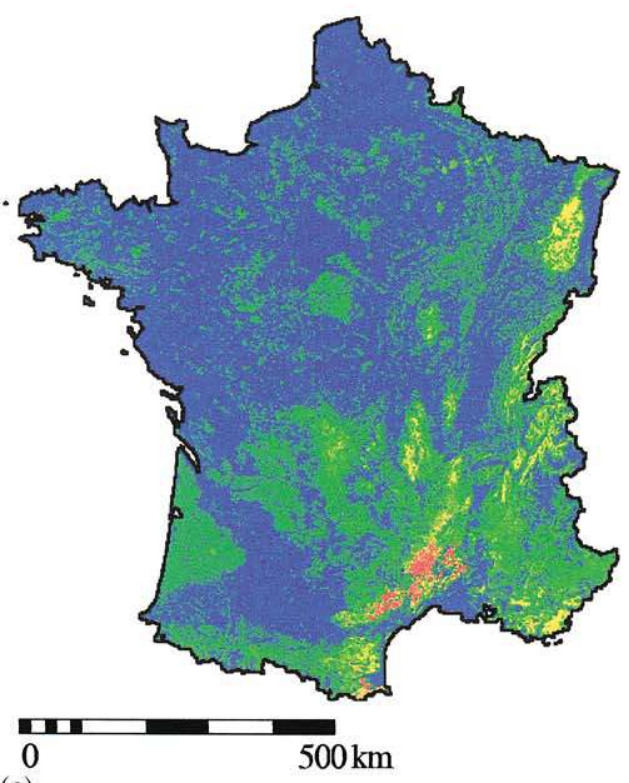

$\mu \mathrm{g} \cdot \mathrm{m}^{-2} \cdot \mathrm{h}^{-1}$

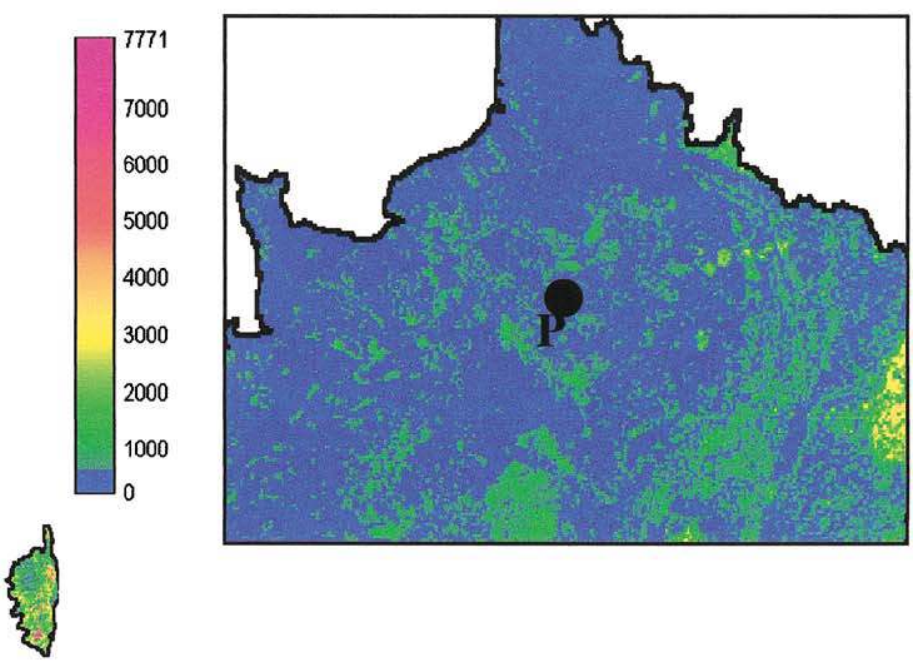

(d)

Fig. 1. Isoprene (a) and monoterpenes (c) emission potentials (in $\mu \mathrm{g} \mathrm{m}^{-2} \mathrm{~h}^{-1}$ ) at $2 \mathrm{~km}$ resolution for France. A zoom over the ESQUIF area is also displayed (b) and (d) (see Section 3). The contribution of non ligneous vegetation (crops and pasture) is very low and does not clearly appear on the map.

(in the North) and $Q$. pubescens (in the Center and the South). For such areas, values range from 16000 to $20000 \mathrm{~g} \mathrm{~m}^{-2} \mathrm{~h}^{-1}$ and are consistent with the European inventory of Simpson et al. (1999) which gives $19200 \mu \mathrm{g} \mathrm{m}^{-2} \mathrm{~h}^{-1}$ for oak ecosystems. Over the Medi- terranean region, we calculated from the inventory a mean isoprene emission potential of $15.3 \mu \mathrm{gg}_{\mathrm{dw}} \mathrm{h}^{-1}$ (here normalized using an average leaf biomass of $300 \mathrm{~g}_{\mathrm{dw}} \mathrm{m}^{-2}$ ). This result is consistent with Guenther et al. (1995) and Owen and Hewitt (2000) estimations 
recommending an isoprene emission potential of $16 \mu \mathrm{g} \mathrm{g}_{\mathrm{dw}} \mathrm{h}^{-1}$ for Mediterranean ecosystems. For monoterpenes, the contribution of coniferous is evident (e.g. in the south western "Landes forest", or in the northeastern "Les Vosges" forest), except in Mediterranean region where the strong emitter $Q$. ilex is predominant. Values obtained for the fir/spruce dominated "Vosges" forest range from $2800-3500 \mu \mathrm{g} \mathrm{m}^{-2} \mathrm{~h}^{-1}$. These values are within the range of Simpson et al. (1999) estimations giving 4200 and $2500 \mathrm{\mu g} \mathrm{m}^{-2} \mathrm{~h}^{-1}$ for fir and spruce dominated ecosystems, respectively. Monoterpenes emission potentials over the "Landes" pine forest are between 1000 to $1500 \mu \mathrm{g} \mathrm{m}^{-2} \mathrm{~h}^{-1}$, i.e. lower than estimations of Simpson et al. (1999) for "pine ecosystems" $\left(2100 \mu \mathrm{g} \mathrm{m}^{-2} \mathrm{~h}^{-1}\right)$. However, the "Landes" forest is dominated by $P$. pinaster, which is a lower emitter than the generic pine species of Simpson's inventory. This example illustrates the need for a method that is based on forestry region and species statistics.

(ii) In the inventory, the species statistics are considered for different ecosystems of each forestry region. Below this scale, the species distribution is not explicitly accounted for, which produces additional uncertainties on emission sources. These 'local' errors are potentially high $(100 \%)$ for forestry region where ecosystems are dominated by species having very different emission factors (e.g. emitting vs. non-emitting) and associated with clustered spatial distribution, as opposed to well mixed populations.

(iii) For intermediate scales encompassing several forestry regions, the inventory is likely to provide a source distribution more refined compared to previous European or global estimations, thus reducing biogenic source uncertainties in the scope of regional studies over France. However, basic uncertainties affecting species emission factors (reaching sometimes $50-100 \%$ ) and leaf biomass estimation are still likely to affect the relative magnitude of potential sources.

\subsection{Environmental correction factors and biogenic fluxes}

The environmental correction factors and ensuing biogenic fluxes are calculated online using the MesoNH meso-scale atmospheric model (Lafore et al., 1998). The surface microclimate is simulated through the interactive vegetation scheme ISBA-Ags (Calvet et al., 1998; Noilhan and Mahfouf, 1996; Noilhan and Planton, 1989). For a given canopy, the ECF is calculated as

$\mathrm{ECF}=\frac{1}{h} C_{\mathrm{T}}\left(T_{\mathrm{S}}\right) \int_{0}^{h} C_{\mathrm{L}}($ par $) \mathrm{d} z$,

where $h$ is the representative canopy height $(\mathrm{m}), C_{\mathrm{L}}$ and $C_{\mathrm{T}}$ are the leaf-level emission activity factors depending on photosynthetically active radiation (par) and leaf temperature $\left(T_{\mathrm{S}}\right)$ (Guenther et al., 1995; Guenther,
1999). For the $C_{\mathrm{T}}$ calculation, the ISBA-Ags prognostic surface temperature $T_{\mathrm{s}}$ is assumed to represent the mean leaf temperature throughout the canopy. For $C_{\mathrm{L}}$, the par attenuation in the canopy is calculated assuming a uniformly distributed LAI as prescribed in Roujean et al. (1996) and Calvet et al. (1998). For monoterpenes emissions, the ECF only relies on an exponential function of $T_{\mathrm{S}}$, except in $Q$. ilex dominated ecosystem where an isoprene-type algorithm was used (Ciccioli et al., 1997).

Biogenic fluxes are calculated for each sub-grid ecosystem and then averaged at the grid-cell level using Eq. (1). For each of these sub-grid canopies, the corresponding surface parameters (LAI, $h$, roughness, etc.) are defined from the Masson et al. (2003) landuse database. Alternatively to the fully aggregated approach (Noilhan et al., 1989), we considered here sub-grid surface energy budgets to calculate grid-level biogenic emissions. This is particularly important when the model cell covers heterogeneous landscapes because the microclimate of emitters can significantly differ from the gridcell "mean microclimate". However, the calculation of the environmental correction factor is still subject to uncertainties directly affecting the biogenic flux magnitude. Such errors lies in the simple assumption used (e.g. uniform vertical temperature) to describe the canopy as well as on the energy budget itself. For example, in warm atmospheric conditions, a local error of $3^{\circ} \mathrm{C}$ on leaf temperature estimation can induce a variation of $30-40 \%$ of biogenic fluxes.

\section{Impact of biogenic fluxes on regional pollution}

The biogenic emission model was used to study in the Intensive Observation Period 2 (IOP2) of the ESQUIF program ("Air quality study and modeling over the Paris area") which was conducted between 1998 and 2001 in the Paris region (Menut et al., 2000). During the IOP2, from the 7th to 10th of August, 1998, anticyclonic conditions with light winds, high sunshine and temperatures prevailed and favoured pollution over the whole northern France. In the Paris urban plume, high $\mathrm{O}_{3}$ concentrations near the surface were observed on the 8th and 9th of August. For these two days, we investigated the specific role of biogenic emissions in the regional ozone formation.

\subsection{Model and method overview}

The MesoNH-C atmospheric chemistry model results from the online coupling of the ReLACS (Regional Lumped Atmospheric Chemical Scheme) module to the previously mentioned MesoNH (Shure et al., 1998; Tulet et al., 1999, 2003). ReLACS contains 37 species (notably isoprene and monoterpenes) for 128 reactions and has 
been previously validated for clean to polluted air conditions (Crassier et al., 2000). Species dry deposition is also considered (Tulet et al., 2002). Over urban areas, the MesoNH-C model uses the Town Energy Budget TEB (Masson, 2000).

We selected a $795 \mathrm{~km} \times 795 \mathrm{~km}$ domain, centered on Paris, with a $15 \mathrm{~km}$ horizontal resolution. We used a 60 -level vertical grid with a resolution of $40 \mathrm{~m}$ near the surface increasing regularly to the top at $14000 \mathrm{~m}$ (20 levels are between 0 and $1000 \mathrm{~m}$, enabling a detailed representation of the boundary layer). The 3-day simulations started on 7th of August at 00:00 UTC. Meteorological parameters were initialized and forced at the boundaries every $6 \mathrm{~h}$, using output coming from the French operational forecast model ARPEGE.

Each chemical compound was initialized by a vertical profile, constant throughout the domain. The ozone profile was specified using aircraft data for the lower levels between 0 and $1500 \mathrm{~m}$, and MOZAIC data for upper levels (Marenco et al., 1998). $\mathrm{CH}_{4}$ and $\mathrm{CO}$ were initialized to typical background values (1700 and $100 \mathrm{ppb}$ between 0 and $300 \mathrm{~m}$, respectively, decreasing in the higher layers). The short-lived compounds were initialized to zero.

Anthropogenic emissions of $\mathrm{NO}_{x}, \mathrm{CO}, \mathrm{SO}_{2}$ and 32 hydrocarbon classes were hourly provided to the model. These emissions came from the GENEMIS European inventory (Wickert et al., 1999), accounting for anthropogenic sources like traffic, industries, solvent use, waste treatment and agriculture. The initial resolution of this inventory was $3 \mathrm{~km}$ in the Paris region, and $9 \mathrm{~km}$ elsewhere and then aggregated at the model grid cell. In the next section, we compared results obtained with and without biogenic emissions (BIO and NOBIO case).

\subsection{NOBIO control simulations}

\subsubsection{Temperatures}

Fig. 2 compares simulated and measured air temperatures at $2 \mathrm{~m}$ at 15:00 UTC. The simulation reproduces the observation within a range of $1^{\circ} \mathrm{C}$ to maximum $3^{\circ} \mathrm{C}$, with a slight tendency to overestimate locally. At the regional scale, the model does a good job in reproducing the observed temperature gradients, which is important in simulating a realistic underlying surface energy budget throughout the domain. High temperatures $\left(>30^{\circ} \mathrm{C}\right)$ were observed, implying high surface temperatures (between $30^{\circ} \mathrm{C}$ and $40^{\circ} \mathrm{C}$ ) and biogenic fluxes.

\subsubsection{Anthropogenic ozone and $N O_{x}$}

On 8 August, an ozone pollutant plume develops at $60 \mathrm{~km}$ north west of Paris, in which simulated concentrations reaches as high as $95 \mathrm{ppb}$ at 15:00 UTC (Fig. 4a). Elsewhere, the ozone concentrations range between 55 and $75 \mathrm{ppb}$ for the Northern Lille domain. Looking to the precursor $\mathrm{NO}_{x}$ field, the highest concentrations (Fig. 3a) are found in Paris, and in the Benelux industrialized area (Northeast limit of the domain). The Paris primary pollutant $\mathrm{NO}_{x}$ plume extends as far as $100 \mathrm{~km}$ downwind of the metropolitan area. Elsewhere, $\mathrm{NO}_{x}$ concentrations are low, except for a localized zone near the Luxembourg boarder.

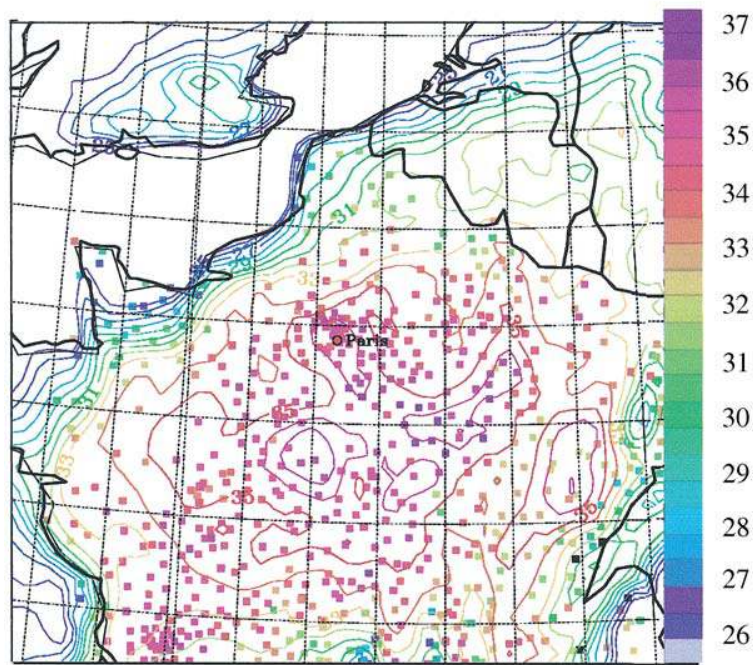

(a)

August 8th, 1998 15:00 UTC

37
36
35
34
33
32
31
30
29
28
27
26

Fig. 2. (a-b) Comparison of observed and simulated air temperatures at $2 \mathrm{~m}$. The observations, represented by colored squares, are issued from the Meteo-France station network. The colored isolines represent the simulated temperature field. 


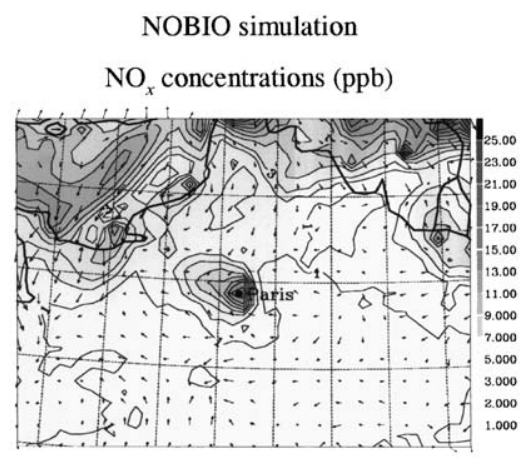

(a) August 8th, 1998 13:00 UTC

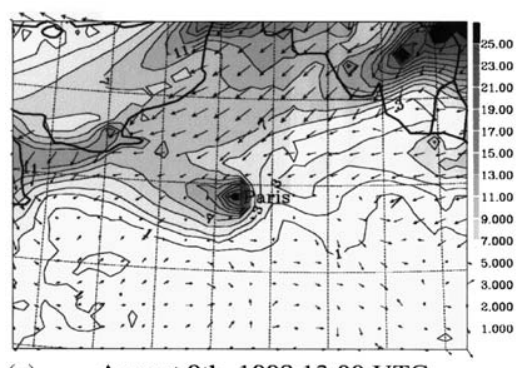

(c)
August 9th, 1998 13:00 UTC
BIO simulation

Biogenic fluxes (ppb.m.s. $\mathrm{s}^{-1}$ )

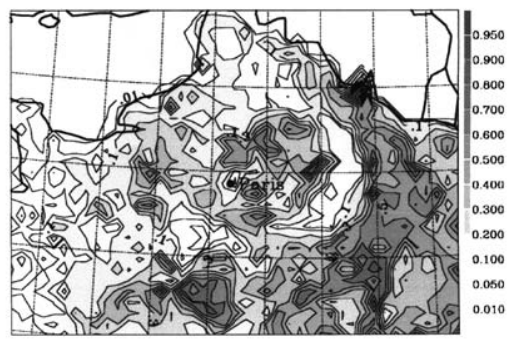

(b) August 8th, 1998 15:00 UTC

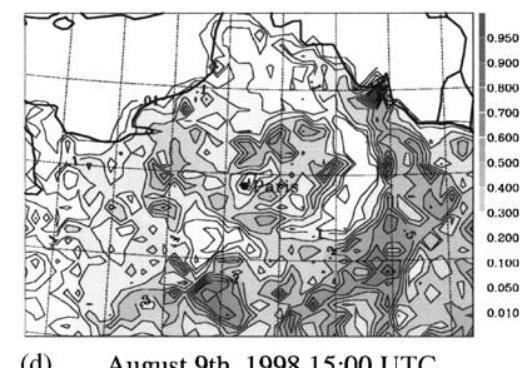

(d) August 9th, 1998 15:00 UTC

Fig. 3. (a), (c): Simulated $\mathrm{NO}_{x}$ concentrations (ppb) in surface, obtained from reference NOBIO simulations 2 (13:00 UTC). (b), (d): Simulated biogenic fluxes (isoprene + monoterpenes, $\mathrm{ppb} \mathrm{m} \mathrm{s}^{-1}$ ), obtained from BIO simulations at 15:00 UTC.

On 9 August (Fig. 4c), the Paris city ozone plume extends to the Paris western area, with a simulated maximum concentration of $95 \mathrm{ppb}$ at 15:00 UTC. Relatively high ozone concentrations, reaching about $85 \mathrm{ppb}$, are also present over a large region extending from Paris, up to the eastern boarders. This larger scale pattern results from an important north-easterly advection of primary pollutants: the $\mathrm{NO}_{x}$ field (Fig. 3b) is much more extensive than on 8 August (Fig. 3b), with significant concentrations found in rural areas in addition to the Paris plume. Low ozone concentrations were found in the northern part of the domain. This was attributed to the combined effect of the advection of clean air from the boundaries, and a ' $\mathrm{NO}_{x}$ titration' effect (i.e. the relative consumption of ozone by $\mathrm{NO}$ in excess; Sillman, 1999) close to northern large anthropogenic sources.

\subsection{Biogenic emission impacts}

Figs. $3 \mathrm{~b}$ and d display the simulated biogenic fluxes for the 8 and 9 August at 15:00 UTC. Over the domain, fluxes spatial patterns are mainly determined by isoprene emission potential distribution (Figs. $2 b$ and d). In the area surrounding Paris, significant isoprene emissions range from 0.1 to $0.55 \mathrm{ppb} \mathrm{m} \mathrm{s}^{-1}(\sim 1500$ $\left.5000 \mu \mathrm{g} \mathrm{m}^{-2} \mathrm{~h}^{-1}\right)$. The largest isoprene emissions reaching $0.9 \mathrm{ppbm} \mathrm{s}^{-1}\left(\sim 8000 \mu \mathrm{g} \mathrm{m}^{-2} \mathrm{~h}^{-1}\right)$ are found for forested areas situated at the east and southeast of Paris, and extending up to northeastern boarder.

For the near-surface ozone fields, comparisons of NOBIO and BIO simulations are presented (Fig. 4). Measurements provided from 13 stations of the French air quality network are also superimposed on the simulated fields. In most of the case, the 15:00 UTC measured values are close to the maximum diurnal ozone concentrations reached at each location. For specific stations pointed out in Fig. 4, temporal evolutions of measured and simulated ozone concentrations are compared (Fig. 5). Stations are situated in the Paris plume (Mantes la Jolie, Mn), in eastern France (Bar le Duc, Bd, semi-rural), and in the western part of the domain (Brotonne, $\mathrm{Br}$, rural).

\subsubsection{8th August 1998}

In the Paris plume, the biogenic emissions induce an increase in ozone surface concentrations (Figs. 4a and b). In the plume maximum, the concentrations reaches about $18 \mathrm{ppb}$, i.e. $+18 \%$ when compared to the NOBIO simulation. The presence of significant $\mathrm{NO}_{x}$ concentrations downwind of Paris induce a "VOC-sensitive" chemical regime (Sillman, 1999), characterized by a rather low anthropogenic $\mathrm{COV} / \mathrm{NO}_{x}$ ratio. This favors the downwind ozone production from biogenic precursors formed near the isoprene sources. Inside Paris urban area, the $\mathrm{NO}_{x}$ titration occurs, resulting in a more 
NOBIO simulation

Surface $\mathrm{O}_{3}$ concentrations (ppb)

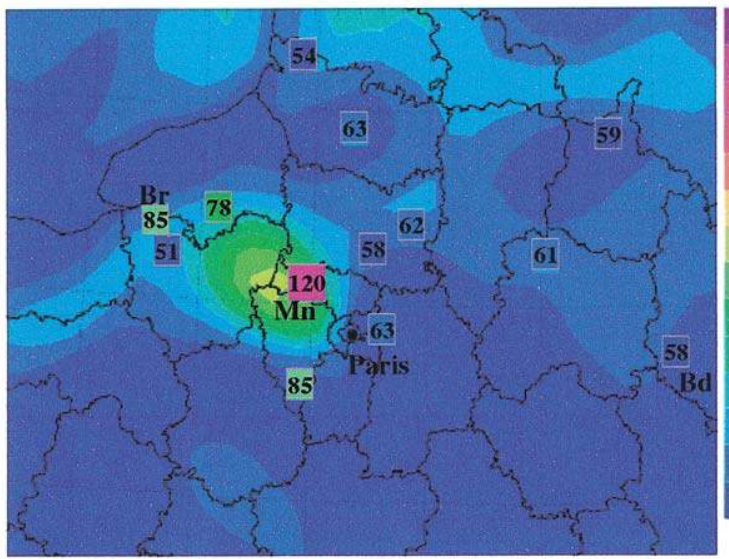

(a)

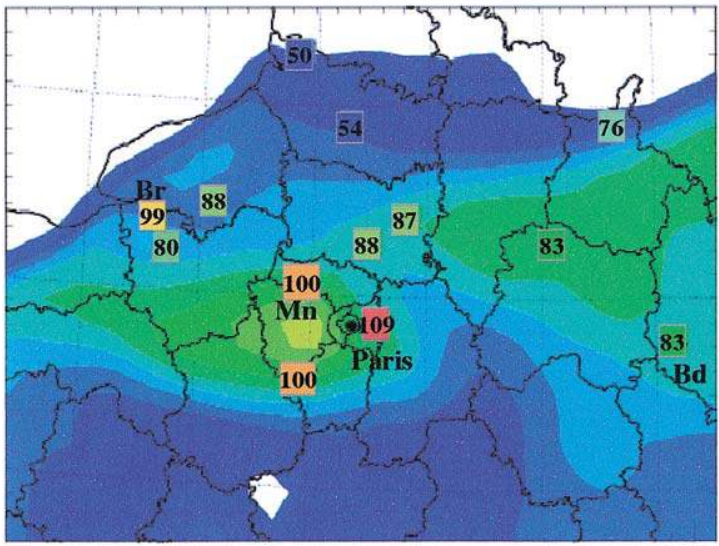

(c)
August 8th, 1998 15:00 UTC

August 9th, 1998 15:00 UTC
BIO simulation

Surface $\mathrm{O}_{3}$ concentrations (ppb)

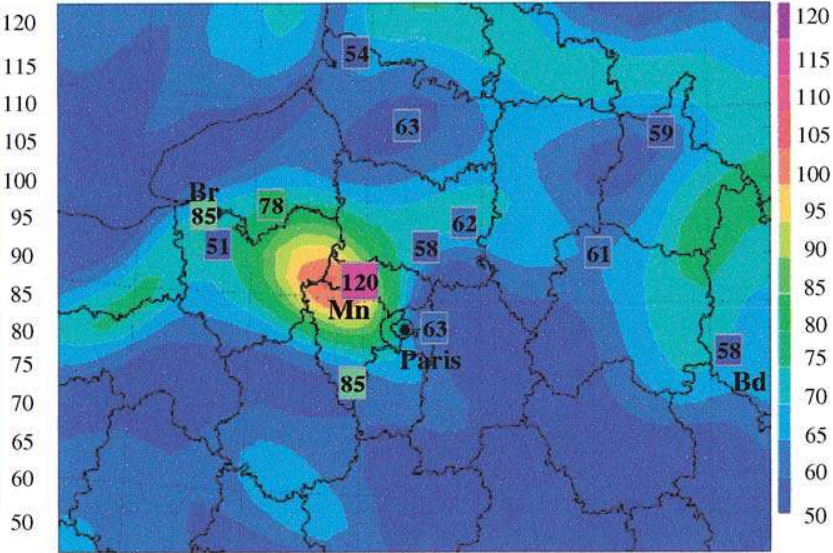

(b)

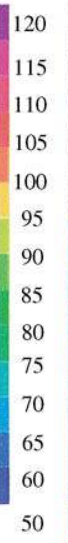

-
$5=-$
5
5

(d)

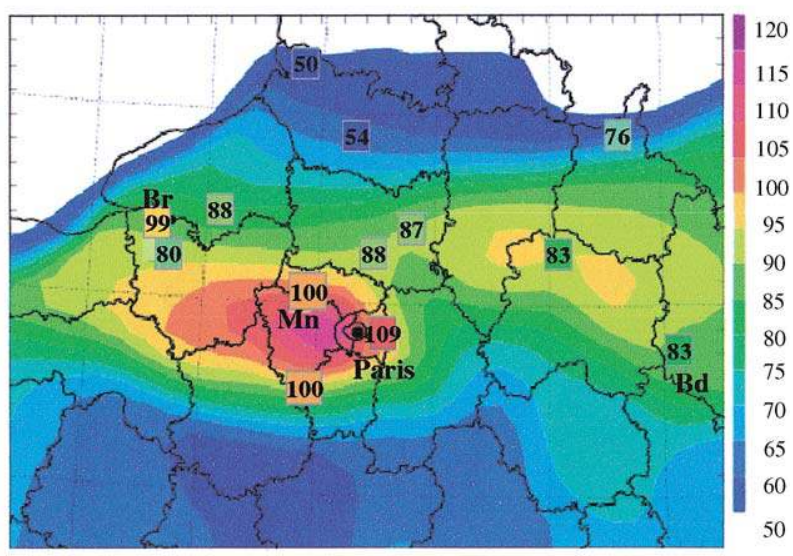

August 9th, 1998 15:00 UTC

Fig. 4. Comparison between simulated ozone surface concentrations obtained without biogenic emissions (NOBIO) and with biogenic emissions (BIO) for 8 and 9 August 1998, 15:00 UTC. Ozone concentration measurements for available stations of the French air quality network are overlaid on simulated fields. $\mathrm{Mn}, \mathrm{Bd}$ and $\mathrm{Br}$ symbols denote stations where the temporal evolution of concentrations are reported (cf. Fig. 5 and text).

moderate ozone production. In the Paris plume, the introduction of biogenic emissions leads to an improvement of simulated ozone fields at 15:00 UTC. At the $M n$ station, the diurnal evolution of ozone concentrations is also better represented when accounting for biogenic emissions (Fig. 5a).

Apart from the Paris plume, the maximum relative increase due to biogenic emissions occurs in a rural area close to the Luxembourg boarder. The upwind $\mathrm{NO}_{x}$ sources (Fig. 3a), in conjunction with the strong isoprene fluxes (Fig. 3b) enables a $20 \mathrm{ppb}$ ozone increase, i.e. a relative biogenic impact reaching about $+30 \%$.
At the eastern Bd rural station, the maximum ozone concentration (reached around 13:00 UTC) is better estimated when accounting for biogenic emission (Fig. 5b). However for this station, the observed ozone dissipation in the afternoon is not well represented in both BIO and NOBIO simulations. This probably relies on local dynamics not precisely simulated over the measurement point. In the rural $\mathrm{Br}$ rural station, we observe also a slight improvement of simulated ozone peak in the BIO case (Fig. 5c). Elsewhere, a less significant increase, varying between 2 and $6 \mathrm{ppb}$, is obtained with the introduction of biogenic emissions. 

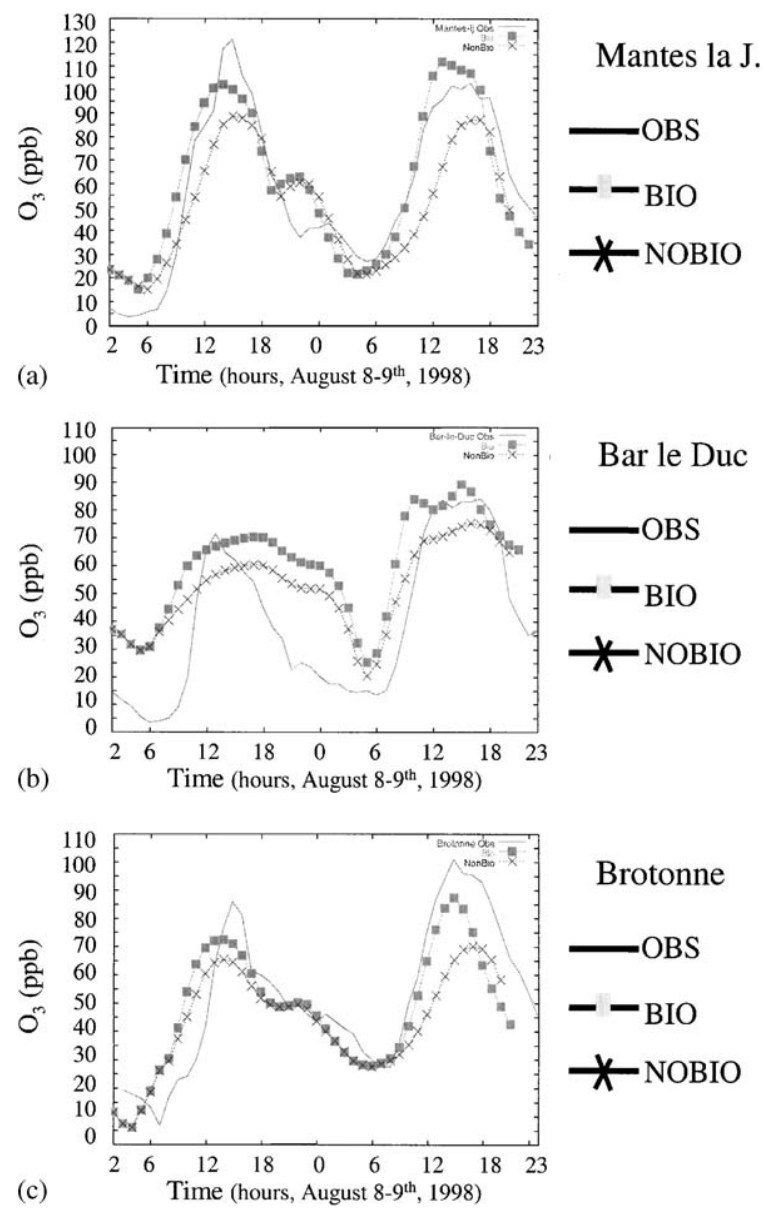

Fig. 5. Evolution of measured and simulated ozone concentrations for 3 stations (Mn: Mantes-la-jolie, Bd: Bar-le-duc, Br: Bretonne forest, see also Fig. 4) for 8 and 9 August, 1998. Simulations are performed without (NOBIO) and with (BIO) biogenic emissions.

\subsubsection{9th August 1998}

In the Paris plume maximum (west of Paris, Figs. 4c and $\mathrm{d}$ ), the increase of ozone reaches $+30 \mathrm{ppb}$ (a relative biogenic contribution of about $+31 \%$ ). Compared to the previous day, this contribution is significantly higher despite the fact that Paris $\mathrm{NO}_{x}$ emissions and surrounding biogenic fluxes do not significantly differ. The Paris ozone plume is in fact strengthened by the larger scale upwind ozone increase. The anthropogenic $\mathrm{NO}_{x}$ advected from northeastern polluted areas (Fig. 3b) have induced VOC-sensitive conditions over a large east-west strip (east/northeast to Paris), and consequently a significant biogenic ozone production on this area (Figs. $4 \mathrm{c}$ and $\mathrm{d})$.

Downwind of Paris, accounting for biogenic emissions resulted in a general improvement of simulated ozone field. The ozone concentration enhancement result in a better fit with measurements at 15:00 UTC
(Figs. 4c and d). This improvement was also confirmed on the diurnal evolution of ozone concentrations at the Mn stations (Fig. 5a). In the remote $\mathrm{Br}$ rural station, the biogenic emissions had a significant impact and improved the simulation of both ozone evolution and maximum concentration (Fig. 5c).

In high emitting regions (east of Paris on Fig. 4d), the contribution of biogenic compounds to the ozone field can reach $+26 \mathrm{ppb}$ (i.e. $+27 \%$ of relative contribution). We note an improvement of simulated ozone field at 15:00 UTC upwind of Paris (Figs. 4c and d). Over the eastern Bd station, the highest diurnal ozone concentrations are better simulated in the BIO case (Fig. 5b), and match quite closely with the measurements.

\section{Conclusion}

A new database of isoprene and monoterpenes emission potentials was established over France at $2 \mathrm{~km}$ resolution. In the up-scaling method, we used species emissions factors together with fine landuse database and forest statistics relying upon an ecological partition of the territory (forestry regions). Showing consistency with previous inventories at large scale, the developed emission potential is likely to bring precision in the distribution and quantification of biogenic sources for regional application in France. However, for local scale domain, (i.e. smaller than forestry regions), the ecological variability may not be well accounted for by forest statistics. A finer resolution ecological database giving explicit tree species distributions should be used for emissions potential calculation. Until now, such data are rare in France and only exist in very localized regions. Forthcoming improvement of the emission potential database relies upon the use of satellite measurements to estimate LAI and emitting leaf biomass. Such developments should allow the calculation of seasonal emissions potentials.

Using the MesoNH-C model, we studied the regional chemical impact of biogenic emissions for a pollution event over the Paris area and northern France. Emissions at the landscape scale were calculated on line, using the emission potential database and leaf level algorithm integrated in sub-grid surface energy budgets performed over emitting ecosystems. Numerical simulations showed that biogenic contribution could lead to a maximum relative increase reaching $30 \%$ of surface ozone concentration. This high biogenic impact was due to both high temperatures and radiation levels, in addition to the dynamical and chemical situation, allowing VOC-sensitive air masses to reach biogenic emission areas. For the 9 August 1998, the biogenic emissions induced a simulated ozone increase of $30 \mathrm{ppb}$ in the Paris plume, and a general enhancement over a large east-west strip encompassing urban and rural 
regions. In high isoprene emitting rural areas, the simulated relative ozone increase reached about $27 \%$. Comparisons with ozone measurements showed also a global improvement of ozone simulated fields after the introduction of biogenic emissions, both in the Paris plume and remote locations.

In this study, we outlined that uncertainties affecting biogenic fluxes are still important. The emission potential estimation is certainly the most sensitive issue because it determines whether or not a biogenic source exists and its relative magnitude. The effective emission is also affected by biases in the surface parameterization of the energy budget which determines vegetation temperature and in-canopy radiation. In term of impacts on chemistry and ozone formation, the consequences of these uncertainties are difficult to assess, as the atmospheric chemical processes are strongly nonlinear. Modeling sensitivity studies should furthermore improve the quantification of these impacts. Presumably, they are stronger in regions likely to produce VOCsensitive chemical conditions. Experimental and modeling studies should first identify (geographically and climatologically) such sensitive region in order to define priorities and strategies for biogenic fluxes inventories (see for example, the ESCOMTE 2001 experiment; Cros et al., 2003). Nevertheless, some recent extended summer pollution events (2003) experienced in Europe showed that biogenic emissions may interact with anthropogenic pollution over a wide range of scales, including remote locations. In such cases, default inventories as presented in this study are still required.

\section{References}

Bartelink, H.H., 1997. Allometric relationships for biomass and leaf area of beach (Fagus sylvatica L). Annales Des Sciences Forestieres 54, 39-50.

Benjamin, M.T., Sudol, M., Bloch, L., Winner, A.M., 1996. Low emitting urban forests: a taxonomoic methodology for assigning isoprene and monoterpenes emission rates. Atmospheric Environment 30, 1437-1452.

Cabanettes, A., Rapp, M., 1978. Biomasse, minéralomasse et productivité d'un écosystéme à pins pignons (Pinus pinea L) du littoral méditerranéen. Oecologia Plantarum 13, 271-286.

Calvet, J.C., Noilhan, J., Roujean, J.-L., Bessemoulin, P., Cabelguenne, M., Olioso, A., Wigneron, J.P., 1998. An interactive vegetation SVAT model tested against data from six contrasting sites. Agricultural and Forest Meteorology 92, 73-95.

Chameides, W., Linsay, R., Ridchardson, R., Kiang, C., 1988. The role of biogenic hydrocarbons in urban photochemical smog: Atlanta as a case study. Science 241, 1473-1475.

Chevrou, R.B., 1988. Inventaire forestier national: méthodes et procédures. Note technique de l'Inventaire Forestier National. 45290 Nogent-sur-Vernisson, France.
Ciccioli, P., Fabozzi, C., Brancaleoni, E., Cecinato, A., Frattoni, M., Loreto, F., Kesselmeier, J., Schafer, L., Bode, K., Torres, L., Fugit, J.L., 1997. Use of the isoprene algorithm for predicting the monoterpene emission from the Mediterranean holm oak Quercus ilex L: performance and limits of this approach. Journal of Geophysics Research 102 (D19), 23319-23328.

Corchnoy, S.B., Arey, J., Atkinson, R., 1992. Hydrocarbon emissions from twelve urban shade trees of the Los Angeles, California, Air Basin. Atmospheric Environment 26B (3), 339-348.

Crassier, V., Suhre, K., Tulet, P., Rosset, R., 2000. Development of a reduced chemical scheme for use in mesoscale meteorological models. Atmospheric Environment 34, 2633-2644.

Cros, B., Durand, P., Frejafon, E., Kottmeier, C., Perros, P.E., Peuch, V.H, Ponche, J.L., Robin, D., Saï, F., Toupance, G., Wortham, H., 2003. The ESCOMPTE program: an overview. Atmospheric Research 69, 3-4, 241-279.

Damesin, C., Rambal, S., Joffre, R., 1998. Co-occurrence of trees with different leaf habit: a functionnal approach on Mediterranean oaks. Acta Oecologica 19, 195-204.

Duchemin, B., 1999. NOAA-AVHRR bidirectional reflectance: modeling and application for the monitoring of a temperate coniferous forest ecosystem. Remote Sensing Environment 67, 68-82.

Dufresne, E., Breda, N., 1995. Estimation of deciduous forest leaf area index using direct and indirect methods. Oecologia 104, 156-162.

Fall, R., Wildermuth, M.C., 1998. Isoprene synthase: from biochemical mechanism to emission algorithm. Journal of Geophysics Research 103, 25599-25609.

Flyckt, D.L., Westberg, H.H., Holdren, M.W., 1980. Natural organic emissions and their impact oin air quality. Presentation to 73rd Annual Meeting of the Air Pollution Control, Washington State University, Pullman Association, Montreal, Quebec.

Geron, C., Ruark, G.A., 1988. Comparison of constant and variable allometric ratios for predicting foliar biomass of various tree genera. Canadian Journal of Forest Research 18, 1298-1304.

Geron, C., Harley, P., Guenther, A., 2001. Isoprene emission capacity for US tree species. Atmospheric Environment 35 (19), 3341-3352.

Gower, S.T., Norman, J.M., 1991. Rapid estimation of leaf area index in conifer and broad leaf plantations. Ecology 72, 1896-1900.

Gower, S.T., Kucharick, J., Norman, J.M., 1999. Direct and indirect estimation of leaf area index, $\mathrm{f}_{\mathrm{apar}}$, and net primary production of terrestrial ecosystems. Remote Sensing of Environment 70, 29-51.

Granier, A., 1981. Etude des relations entre la section du bois d'aubier et la masse foliaire chez le Douglas (Pseudotsuga menzisii Mirb. Franco). Annales Des Sciences Forestieres 38, 503-512.

Guenther, A., 1999. Modeling biogenic VOC emissions to the Atmosphere. In: Hewitt, C. (Ed.), Reactive Hydrocarbons in the atmosphere. Academic Press, New York, pp. 97-118.

Guenther, A., Zimmerman, P., Wildermuth, M., 1994. Natural volatile organic compound emission rate estimate for US 
woodland landscapes. Atmospheric Environment 28, $1197-1210$

Guenther, A., Hewitt, C., Erickson, D., Fall, R., Geron, C., Graedel, T., Harley, P., Klinger, L., Lerdau, M., McKay, W., Pierce, T., Scholes, B., Steinbrecher, R., Tallamraju, R., Taylor, J., Zimmerman, P., 1995. A global model of natural volatile organic compound emissions. Journal of Geophysics Research 100, 8873-8892.

Guenther, A., Geron, C., Pierce, T., Lamb, B., Harley, P., Fall, R., 2000. Natural emissions of non-methane volatile organic compounds, carbon monoxyde, and oxides of nitrogen from North America. Atmospheric Environment 34, 2205-2230.

Isidorov, V.A., Zenkevich, I.G., Ioffe, B.V., 1985. Volatile organic compounds in the atmosphere of forests. Atmospheric Environment 19 (1), 1-8.

Kesselmeier, J., Staudt, M., 1999. Biogenic volatile organic compounds (VOC): an overview on emission, Physiology and Ecology. Journal of Atmospheric Chemistry 33, 23-88.

Kesselmeier, J., Bode, K., Schafer, L., Schebeske, G., Wolf, A., Brancaleoni, E., Cecinato, A., Ciccioli, P., Frattoni, M., Dutaur, L., Fugit, J., Simon, V., Torres, L., 1998. Simultaneous field measurements of terpene and isoprene emissions from two dominant Mediterranean oak species in relation to a North American species. Atmospheric Environment 32 (NO11), 1947-1953.

Lafore, J.P., Stein, J., Asencio, A., et al., 1998. The meso-NH atmospheric simulation system. Part 1: adiabatic formulation and control simulations. Annales Geophysicae 16, 90-109.

Marenco, A., Thouret, V., Nedelec, P., Smit, H., Helten, M., Kley, D., Karcher, F., Simon, P., Law, K., Pyle, J., Poschmann, G., Von Wrede, R., Hume, C., Cook, T., 1998. Measurement of ozone and water vapor by Airbus in-service aircraft: the MOZAIC airborne program, An overview. Journal of Geophysics Research 103 (D19), 25631-25642.

Martin, G.M., Kloeppel, B.D., Schaefer, T.L., Kimber, D.L., McNulty, S.G., 1998. Aboveground biomass and nitrogen allocation of ten deciduous southern Appalachian tree species. Canadian Journal of Forest Research 28, $1648-1659$

Masson, 2000. A physically based scheme for the urban energy budget in atmospheric models. Boundary Layer Meteorology $94,357-397$.

Masson, V., Champeaux, J.L., Chauvin, F., Meriguet, C., Lacaze, R., 2003. A global database of land surface parameters at $1 \mathrm{~km}$ resolution in meteorological and climate models. Journal of Climate 16, 1261-1282.

Menut, L., Vautard, R., Flamant, C., Abonnel, C., Beekmann, M., Chazette, P., Flamant, P.H., Gombert, D., Guedalia, D., Kley, D., Lefebvre, M.P., Lossec, B., Martin, D., Megie, G., Perros, P., Sicard, M., Toupance, G., 2000. Measurements and modelling of atmospheric pollution over the Paris area: an overview of the ESQUIF Project. Annales Geophysicae A 18 (11), 1467-1481.

Monson, R., Harley, P.C., Litvak, M.E., Wildermuth, M., Guenther, A., Zimmerman, P., Fall, R., 1994. Environmental and developmental controls over the seasonal pattern of isoprene emission from aspen leaves. Oecologia 99, 260-270.
Niinemets, U., Kalevi, K., 1994. Leaf weight per area and leaf size of 85 Estonian woody species in relation to shade tolerance and light availability. Forest Ecology and Management 70, 1-10.

Noilhan, J., Mahfouf, J.F., 1996. The ISBA land surface parameterisation scheme. Global and Planetary Change 13 (1-4), 145-159.

Noilhan, J., Planton, S., 1989. A simple parameterization of land surface processes for meteorological models. Monthly Weather Review 117, 536-549.

Owen, S.M., Hewitt, C.N., 2000. Extrapolating branch enclosure measurements to estimates of regional scale biogenic VOC fluxes in the northwestern Mediterranean basin. Journal of Geophysics Research 105 (D9), 11573-11583.

Owen, S., Boissard, C., Hagenlocher, B., Hewitt, C.N., 1998. Field studies of isoprene emissions from vegetation in the Northwest Mediterranean region. Journal of Geophysics Research 103, 25499-25511.

Pierce, T., Geron, C., Bender, L., Dennis, R., Tonnesen, G., Guenther, A., 1998. Influence of increased isoprene emissions on regional ozone modeling. Journal of Geophysics Research 103, 25,611-25,629.

Pio, C.A., Nunes, T.V., Brito, S., 1993. Volatile hydrocarbon emissions from common and native species of vegetation in Portugal. In: Slanina, J., et al. (Eds.), Proceedings of Joint Workshop of CEC/BIATEX of EUROTRAC, General Assessment of Biog. Emissions and Deposition of Nitrogen Compounds, Sulphur Compounds and Oxidants in Europe, AIR POLLUTION RESEARCH REPORT 47, Aveiro, Portugal, pp. 291-298. ISBN 2-87263-095-3.

Rasmussen, R.A., 1978. Isoprene plant species list. Special Report of Air Pollution Research Section, Washington State University, Pullman.

Seufert, G., Bartis, J., Bomboi, T., Ciccioli, P., Cieslik, S., Dlugi, R., Foster, P., Hewitt, N., Kesselmeier, J., 1997. The BEMA-project: and overview of the Castelporziano experiments. Atmospheric Environment 31 (SI), 79-88.

Sillman, S., 1999. The relation between ozone, $\mathrm{NO}_{x}$ and hydrocarbons in urban and polluted rural environments. Atmospheric Environment 33, 1821-1845.

Simpson, D., Winiwarter, W., Borjesson, G., Cinderby, S., Ferreiro, A., Guenther, A., Hewitt, C.N., Janson, R., Aslam, M., Owen, S., Pierce, T.E., Puxbaum, H., Shearer, M., Skiba, U., Steinbrecher, R., Tarrason, J., Oquist, M.G., 1999. Inventorying emissions from nature in Europe. Journal of Geophysics Research 104, 8113-8152.

Staudt, M., Bertin, N., Frenzel, B., Seufert, G., 1999. Seasonnal variation in amount and composition of monoterpenes emitted by young Pinus pinea trees-implications for emission modeling. Journal of Atmospheric Chemistry $1-23$.

Steinbrecher, R., Hauff, K., 1996. Isoprene and Monoterpenes emission from Mediterranean Oaks. In: Borrell, P., et al. (Eds.), Proceedings of EUROTRAC Symposium 96. SPB Acad. Publish. Bv., The Hague, Netherlands, pp. 229-233.

Steinbrecher, R., Schurmann, W., Schreiner, A.M., Ziegler, H., 1993. Terpenoid emissions from common oak (Quercus robur L.) and Norway spruce (Picea abies L. Karst). In: Slanina, J., et al. (Eds.), Proceedings of Joint Workshop of CEC/BIATEX of EUROTRAC, General Assessment of 
Biog. Emissions and Deposition of Nitrogen Compounds, Sulphur Compounds and Oxidants in Europe, Air Pollution Research Report 47, Aveiro, Portugal, pp. 251-257. ISBN 2-87263-095-3.

Steinbrecher, R., Hauff, K., Rabong, R., 1997. The BEMA-project: isoprenoid emission of oak species typical for the Mediterranean area: source strength and controlling variables. Atmospheric Environment 31 (SI), 79-88.

Stockwell, W.R., Kirchner, F., Kuhn, F., 1997. A new mechanism for regional atmospherical modeling. Journal of Geophysics Research 102, 25847-25879.

Tsigaridis, K., Kanakidou, M., 2002. Importance of volatile organic compounds photochemistry over a forested area in central Greece. Atmospheric Environment 36, 3137-3146.
Tulet, P., Maleej, A., Crassier, V., Rosset, R., 1999. An episode of photooxidant plume pollution over the Paris region. Atmospheric Environment 33, 1651-1662.

Tulet, P., Shure, K., Mari, C., Solmon, F., Rosset, R., 2002. Mixing of boundary layer and upper tropospheric ozone during a deep convective event over Western Europe. Atmospheric Environment 36, 4491-4501.

Tulet, P., Crassier, V., Solmon, F., Guedalia, D., Rosset, R., 2003. Description of the MESO-NH-C model and application to a transboundary pollution episode between northern France and southern England. Journal of Geophysics Research 108, 10.1029/2000JD00301.

Wickert, B., Schwartz, U., Blank, P., John, C., Kuhlwein, J., Obermeier, A., Friedrich, R., 1999. Generation of an emission data base for Europe 1994. Proceedings of Eurotrack Symposium 98 (2), 255-265. 